\title{
Wildlife population control - reproductive physiology under the influence of contraceptive methods in mammalian wildlife, with emphasis on immunocontraception: the best choice? A literature review
}

\author{
Controle da população em animais selvagens - fisiologia reprodutiva sob a \\ influência de métodos anticoncepcionais em animais mamíferos, com ênfase na \\ imunocontracepção: a melhor escolha? Uma revisão da literatura
}

Derek Andrew ROSENFIELD ${ }^{1}$; Cristiane Schilbach PIZZUTTO ${ }^{1}$

${ }^{1}$ Universidade de São Paulo, Faculdade de Medicina Veterinária e Zootecnia,

Departamento de Reprodução Animal, São Paulo - SP, Brazil

\begin{abstract}
Human-wildlife conflicts, a growing and sad reality worldwide, makes population control of wildlife and feral animals one of the biggest challenges in wildlife management, especially due to the rapidly expanding human population, and consequently the ever-diminishing natural habitats of animals. Human activities and the destruction of nature forcing wildlife to move inevitably into urban and agricultural areas, causing "conflicts", such as the risk of zoonosis and traffic accidents, as well as damage to crops in the search for food, whose losses reach millions of dollars. For decades, science has been engaged in extensive efforts to develop methods of "humane" population control methods, and many techniques are being employed in order to control wildlife population. In this article, we present an overview of applied contraceptive methods with simplified graphic demonstrations of their interactions with reproductive physiology, furthermore relating pros and cons of used antifertility agents. These are being compared to a set of desired characteristics for free-ranging wildlife for in-field applications, with emphasis on reversible immunocontraception concluding, therefore, the reasons why this concept is becoming the most appropriate and promising for free-ranging wildlife.
\end{abstract}

Keywords: Wildlife population control. Human-wildlife conflicts. Mammals. Reversible immunocontraceptives.

\section{Resumo}

Os conflitos envolvendo humanos e animais selvagens são uma realidade crescente e triste no mundo inteiro, tornando o controle populacional da fauna silvestre e de animais ferais o maior desafio, principalmente diante do crescimento da população humana e, consequentemente, da diminuição dos habitats naturais dos animais. As atividades humanas e a destruição da natureza forçam os animais de vida livre a se dirigirem para áreas urbanas e agrícolas, o que inevitavelmente causa conflitos, como o risco de zoonoses, acidentes de trânsito, bem como danos às plantações, quando em busca de alimentos, cujo prejuízo chega a milhões de dólares. Durante décadas, a ciência esteve empenhada em esforços extensivos para desenvolver métodos de controle populacional "humano"; e muitas técnicas foram utilizadas para controlar as populações de animais silvestres. Neste artigo será apresentada uma visão geral dos métodos anticoncepcionais aplicados, com demonstrações gráficas simplificadas de suas interações com a fisiologia reprodutiva, bem como relacionando os prós e os contras dos agentes antifertilidade empregados; eles serão comparados com um conjunto de características desejadas para as aplicações em fauna a campo, com ênfase em imunocontracepção reversível, demonstrando, portanto, as razões pelas quais esse conceito se torna o mais apropriado e promissor para animais silvestres de vida livre.

Palavras-chave: Controle de população animal silvestre. Conflitos humanos-animais selvagens. Mamíferos. Imunocontraceptivos reversíveis. 
Correspondence to:

Derek Andrew Rosenfield

Universidade de São Paulo, Faculdade de Medicina Veterinária

e Zootecnia, Departamento de Reprodução Animal

Av. Prof. Dr. Orlando Marques de Paiva, 87

CEP 05508-270, São Paulo, SP, Brazil

e-mail:dro@usp.br

Received: 03/04/2017

Approved: 01/12/2017

\section{Introduction}

The biggest challenge in understanding wildlife reproductive physiology lies within its vast diversity of species. Just in the mammalian class alone, there are more than 5500 known species (INTERNATIONAL UNION FOR CONSERVATION OF NATURE, 2009), every single one with its anatomical and biological particularities. Any campaign to manipulate a species population by employing contraceptive methods demands a dedicated understanding of its reproductive physiology and social makeup to warrant the overall health and well-being of the individual animal as well as of its entire group. Which contraceptive method to choose depends on several aspects, ranging from the species to be treated, gender, age, and reproductive biology to environmental situations, among many others, and there is no "one-product-fitsall" solution. Moreover, most contraceptive products are developed and optimized for human use, and almost exclusively for women. Although approved by regulatory authorities, and tested for safety and efficiency, there are still many reported adverse effects in humans, let alone potential health concerns in wildlife species. Modern contraceptives can manipulate biological processes at any point of the reproductive process, for instance preventing hormone synthesis at the hypothalamus and pituitary glands by hindering receptor expression or by blocking receptors, ceasing gametogenesis, impeding sperm motility, or blocking sperm-ovum diffusion, just to name a few (DELVES et al., 2002; ASA, 2005; COOPER; LARSEN, 2006; PICKARD; HOLT, 2007; KIRKPATRICK, 2011; KAUR; PRABHA, 2014; KOGAN; WALD, 2014).

But why is wildlife population control even an issue? Mainly, it is an attempt to control and minimize humanwildlife conflicts, such as urban invasions, agricultural destructions, attacks on livestock and humans, besides the spread of zoonotic diseases, among others. Moreover, it is also important for land management, or due to space limitation in captivity, as well as the noble efforts to guarantee species survival, where genetic variance comes into play.

This review attends to the understanding of the dynamics of contraceptive methods and its interactions with the mammalian reproductive physiology and endocrinology, as well as associated adverse impacts. Emphasis is given on immunocontraceptive concepts, illustrating the attributes that make this strategy, for the time being, perhaps the most practicable alternative to control free-ranging wildlife population.

\section{Briefly: the hypothalamic-pituitary-gonadal axis (HPG axis)}

Even though the hypothalamus, the pituitary, and the gonadal glands are distinct entities, in their performance of controlling the reproductive function (among several other duties) they work together and depend on one another. The hypothalamus, an organ that regulates many homeostatic functions and responds to ambient influences (stimuli), drives many physiological and behavioral processes. To illustrate: a male perceives a female in heat by sensing her pheromones; sight and physical contact are all stimuli that trigger the male's sexual behavior, exhibited by fights between males for dominance and mating rights, urging sexual arousal, mounting, intromission, and ejaculation. The pituitary gland, or hypophysis, is divided into three lobes: the anterior, or adenohypophysis (adeno $=$ relating to gland), the intermediate, and the posterior lobe, synthesizing and secreting hormones responsible for the regulation of a wide range of physiological functions. Concerning reproduction, the gonadotropins Luteinizing Hormone (LH) and the Follicular Stimulating Hormone (FSH) from the adenohypophysis, regulated by the hypothalamic Gonadotrophin-releasing Hormone ( $\mathrm{GnRH})$, are the chief reproductive hormones. These two glands are connected by the hypophyseal portal system that supplies the blood and therefore the passageway for hormones. The hormones GnRH, LH, and FSH are identical in male and female mammals, with the same general regulatory role of gonadal activities (Figure 1), which is stimulating sex hormone synthesis and gametogenesis, although this is not their only function. These hormones are one of the principal targets regarding contraceptive agents and their applicability in both sexes. Reproductive hormones follow a very precise hierarchy, or pathway, referred to as the hypothalamic-pituitary-gonadal axis (HPG-axis), which functions like a cascade. Nonetheless, that does not imply a one-way signaling street only, as regulatory messengers do also travel in the opposite direction, 
called a positive or negative feedback loop, controlling the continuation of hormone synthesis and secretion. In males, the HPG axis and feedback control are significantly simpler than in females, for obvious reasons (not having estrous cycles, pregnancy, and birth). During Positive Feedback, the GnRH stimulates the release of gonadotropins, and subsequently LH and FSH stimulate Testosterone (T) synthesis mainly within the testis and spermatogenesis. During Negative Feedback, triggered by an increased plasma concentration of inhibin and peak T concentrations, secreted by the Sertoli and Leydig cells respectively, causes an inhibition of GnRH, LH, and FSH secretion; it is further believed that estrogen also plays a regulatory role in testosterone production (ABNEY, 1999; PINEDA et al., 2003; NELSON, 2005; CUNNINGHAM; KLEIN, 2007; JOHNSON, 2013).

In females, feedback signaling is more complex, as it depends on the different phases of the estrous cycle (Figure 2); though distinct events, they depend on each other. In most mammalian species, leading from the follicular phase to ovulation and to the luteal phase is only interrupted by pregnancy or cessation of the ovarian activity either by menopause, pathology, adverse ambient conditions, chronic stress, or suppression by contraceptive methods.

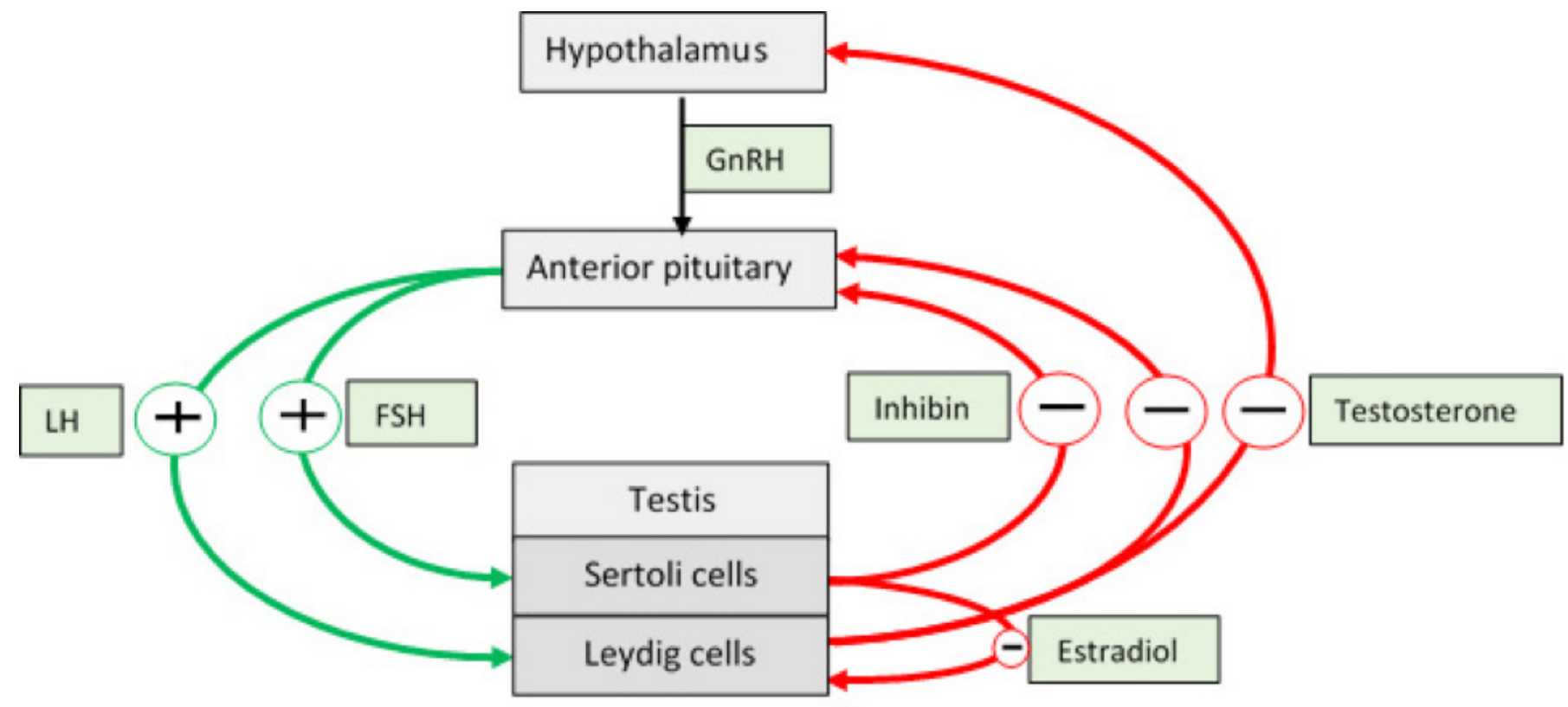

Figure 1 - Simplified representation of the male's Hypothalamic-Pituitary-Gonadal (HPG) axis and reproductive feedback loops. Grey fields, location of hormone receptors and synthesis; Green fields reproductive hormones. Green arrows: positive feedback loop (stimulatory) and red arrows: negative feedback loops (inhibitory).

Source: adapted from Mac Hadley and Jonathan Levine (2007) and Rosenfield (2016)

Feedback-loops during follicular phase: positive feedback - GnRH stimulates the secretion of LH and FSH, which in turn drive the ovarian follicle growth; negative feedback - the ovarian follicles synthesize and secret Estradiol (E2). After reaching peak concentrations, GnRH decreases, keeping LH and FSH secretion to a minimum.

During ovulation: positive feedback only - continuous release of GnRH maintains $\mathrm{LH}$ and FSH secretion, triggering ovarian follicle growth and eventually leading to the formation of dominant or matured follicle(s), starting to produce E2, subsequently liberating an oocyte. Initially secreted E2 also promotes thickening and vascularization of the endometrium.
During luteal phase: positive feedback - after ovulation, the follicle tissue, under the influence of $\mathrm{LH}$, transforms into a corpus luteum (CL), and together with FSH maintains estrogen secretion; negative feedback - The CL starts to secrete the progesterone (P4). Increased plasma levels of P4 and E2 will act on the hypothalamus, as well as on the anterior pituitary, causing an inhibition of $\mathrm{GnRH}, \mathrm{LH}$, and FSH, driving down follicle activity as, simultaneously, endometrial lining develops, preparing the uterus for potential pregnancy (NUSSEY; WHITEHEAD, 2001; PINEDA et al., 2003; FELDMAN; NELSON, 2004; NORRIS; CARR, 2013; SQUIRES, 2013). 


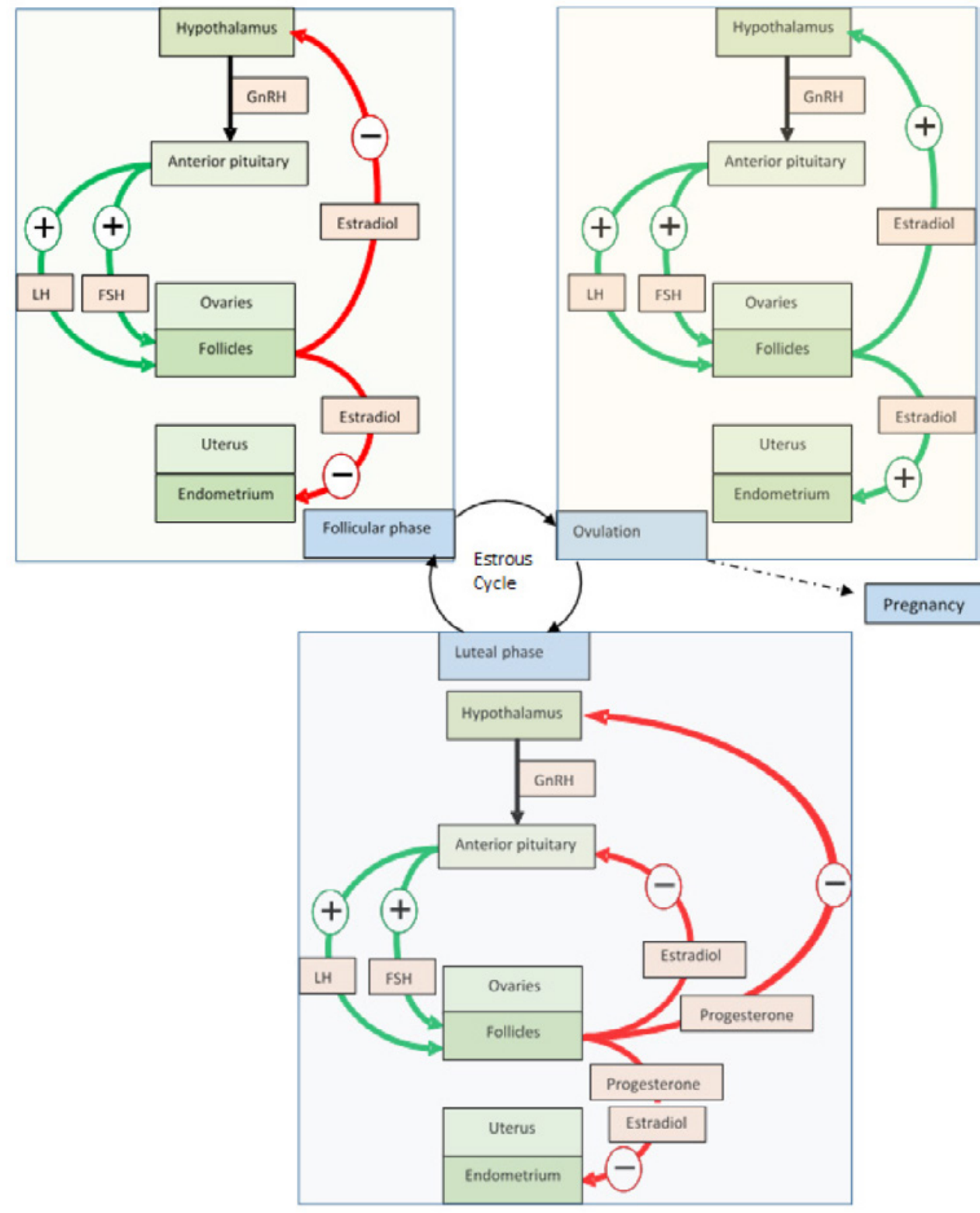

Figure 2 - Female HPG-axis and feedback loops, depending on the phase of the estrous cycle Source: adapted from Mac Hadley and Jonathan Levine (2007) and Rosenfield (2016)

\section{Ligands and receptors: the "key" to unlock contraceptive mechanisms}

Hormones, neurotransmitters, and pheromones are examples of ligands, because of their binding activity with a specific receptor protein, located either on the surface of the cell, within the cytoplasm, or in the nucleus. Specific means that a ligand molecule must "fit" the receptor like a key in a lock, and the better it does (rate of binding), the better the response. A binding prompts the receptor to a conformational change (shape), initiating the cell's signaling cascade, leading to a cell response. The biggest pharmacological challenge is to design a perfect ligand that only binds to its designated receptor. Pharmacological development is human-market driven, leaving the development for wildlife species-specific contraceptives a low priority, if at all, and its focus of application lies with domestic animals, leaving for wildlife management only what is generally obtainable, steroid hormone-based contraceptives being the most common and most frequently used. Nevertheless, as relayed by numerous published studies, these methods, depending on the species, carry a bad reputation for serious side effects, provoked by unwanted activation of non-target receptors, causing several physiological and behavioral side effects, especially in carnivore species. A typical example: in female synthetic androgens may bind to $\mathrm{P} 4$ receptors, mimicking progesterone-like cell signaling, consequently modulating endometrium function, leading to uterine pathologies; or synthetic P4s, known to induce hypersecretion of growth hormones, responsible for the development of cystic endometrial hyperplasia (LODISH, 2000; BHATTI et al., 2007; MORESCO et al., 2009; GREGOIRE, 2013; ASA et al., 2014). 
Before a ligand can bind to a cell, its receptors must be adequately expressed (quantity) to bring about a biological effect, which depends on the physiological necessity. In some processes, the cell undergoes a "priming", or upregulating, describing the event of amplifying the number (expression) of receptors. Inverse to that, there is "downregulation", or a reduction of receptors.

\section{An example of a contraceptive-driven down- regulation, or desensitization}

GnRH-stimulated gonadotropin secretion may be inhibited by using GnRH antagonists (physically blocking the receptor), or by application of a GnRH agonist ( $\mathrm{GnRH}$ analog) that due to constant exposure may provoke desensitization (inactivation of receptors), or by downregulation (decreased receptor expression), ultimately resulting in reduced gonadal activity. Noteworthy, in the case of a GnRH agonist there is an initial "paradoxical" response, a flare effect, exhibiting an increase in plasma LH and FSH levels, followed by a sharp decrease (FINCH et al., 2009).

\section{Male reproductive physiology under the influence of contraceptives}

In males, the primary reproductive organs are the testes, responsible for steroid genesis and spermatogenesis, controlled by LH and FSH secreted in a pulsatile pattern and regulated by the positive feedback of GnRH and the negative feedback of Testosterone (Figure 3). Testosterone, the chief testicular androgen, is synthesized from cholesterol, primarily within the Leydig cells of the testes. However, its synthesis also occurs in other organs, such as the adrenal cortices in both sexes and in female ovarian theca cells, in the placenta during pregnancy, and even in the skin (ZOUBOULIS, 2009). Testosterone's first androgenic effects take place during sexual differentiation in the developing fetus, during maturation of the male sex organs, during growth and puberty, and throughout adulthood to sustain spermatogenesis - plus, its bearing on the development and maintenance of secondary sexual characteristics, physical and behavioral (aggression). In fact, many studies investigate antifertility drugs to control intramale aggression, a dilemma in several captive-held species (PENFOLD et al., 2002; FERRIE et al., 2011; RACHEL, 2012). Unfortunately, one of the undesired consequences is the negative effects on male adornments, meaning the lion's mane; elk or deer antlers; bird's plumage; scent-marking glands, like the nasal Morillo of capybaras, and muscular appearance. Estrogen, however, thought of as a female sex hormone, is being synthesized from Testosterone in the Sertoli cells, controlled by FSH, believed to play an inhibitory role in the secretion of Testosterone from the Leydig cell (ABNEY, 1999). Likewise, there are several other cell-signaling molecules being produced and co-regulating Testosterone synthesis. Sertoli cells also secrete a transport protein, called androgen-binding protein, important in its role to concentrate Testosterone in the seminiferous tubules and to carry it throughout the body (SIMPSON et al., 1999; PINEDA et al., 2003; CLARKE; POMPOLO, 2005; BERGER et al., 2007; CUNNINGHAM; KLEIN, 2007; MEAD et al., 2007; REITER et al., 2009; ZOUBOULIS, 2009; TASSIGNY; COLLEDGE, 2010; ROTSTEIN, 2013).

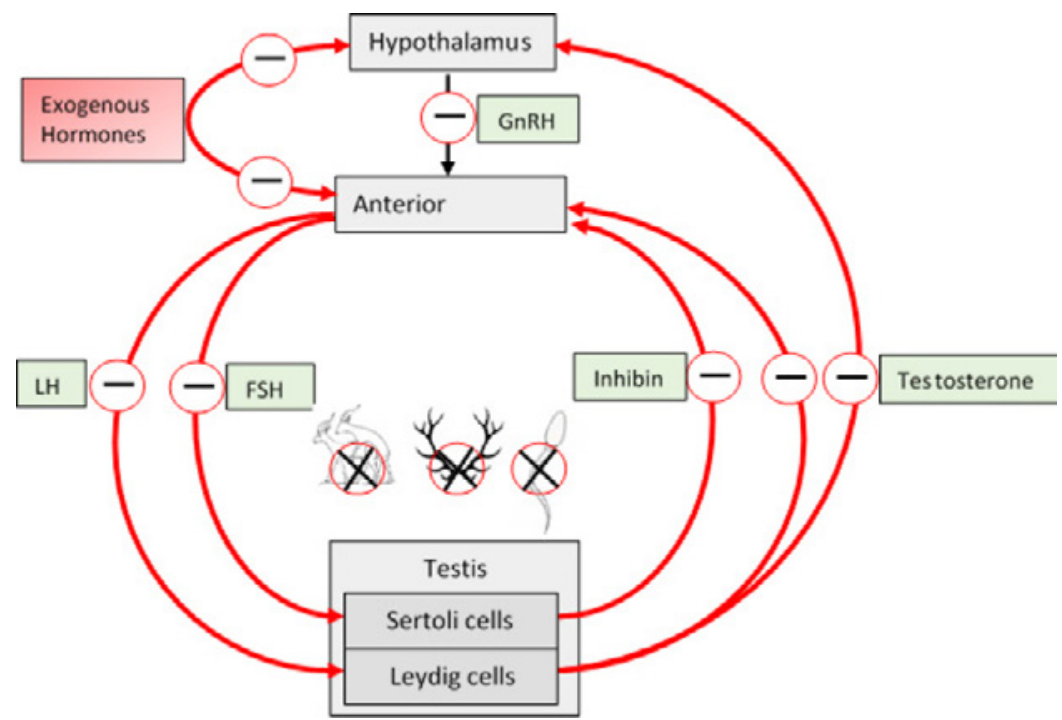

Figure 3 - Example of negative feedback signaling while under the influence of contraceptives

Source: adapted from Mac Hadley and Jonathan Levine (2007) and Rosenfield (2016) 


\section{Persistent testosterone levels after chemical or surgical castration}

We do know that successful inhibition of gametogenesis is achieved after castration, either chemical or surgical. We also understand that, despite castration, there is still a certain plasma testosterone level present, maintained by adrenal androgen synthesis. The question remains, though: does Testosterone synthesis from androgens other than the testis reach efficient plasma concentrations to have an impact on sexual/aggressive behavior or any other gender-specific characteristics? An important question if considering testosterone-depending behavioral traits, which govern social group dynamics such as establishing and maintaining the dominant hierarchical group structure, imperative for its very survival. This is the reason why in captive animals, in free-ranging individuals, or in smaller groups vasectomy is the contraceptive method of choice, allowing minute changes in the overall androgen plasma concentration. However, depending on species and physical location, it is not a feasible "in-the-field" alternative, especially on a greater scale (PINEDA et al., 2003; CHESTER-JONES et al., 2013; NISHIYAMA, 2014).

\section{Female reproductive physiology under the influence of contraceptives}

Female endocrinology, in comparison, is far more complex because of the obvious: conception, embryo development, birth, and the nourishment of the newborn. The two principal female gonadal steroid hormones are estradiol (E2) and progesterone (P4), such as in males, synthesis and secretion are chiefly under the influence of GnRH and Gonadotropins. E2 is synthesized in the ovary's theca interna and granulosa cells; controlled by positive feedback mechanism of LH and FSH, aided by Activin, and regulated by the negative feedback when E2 reaches peak plasma concentrations, acting on GnRH and Inhibin on FSH synthesis (Figure 4). Moreover, depending on the species-specific reproductive characteristics, such as being seasonal or non-seasonal breeders, mono- or polyestrous, and having spontaneous or induced ovulation, each has its unique endocrinological functioning. Similar to the male testosterone, estrogen is responsible for developing the female reproductive organs and for the maintenance of secondary sex characteristics, including sexual behavior (receptiveness for mating), also referred to as behavioral estrus. Another ovarian hormone is the Oocyte Maturation Inhibitor (OMI), responsible for the preservation of the oocytes during the arrest stage. Inhibin, like in males, blocks the secretion of $\mathrm{FSH}$, while Gonadocrinin influences the steroid genesis in the theca cells (a layer of the ovarian follicles). In addition, Activin and Relaxin play their roles in ovarian activity and parturition, respectively. Ambient and physical conditions influence the female cyclicity, which is why contraceptive effects on the reproductive physiology can be complex and irregular (SIMPSON et al., 1999; PINEDA et al., 2003; CLARKE; POMPOLO, 2005; BERGER et al., 2007; CUNNINGHAM; KLEIN, 2007; MEAD et al., 2007; REITER et al., 2009; ZOUBOULIS, 2009; TASSIGNY; COLLEDGE, 2010; ROTSTEIN, 2013).

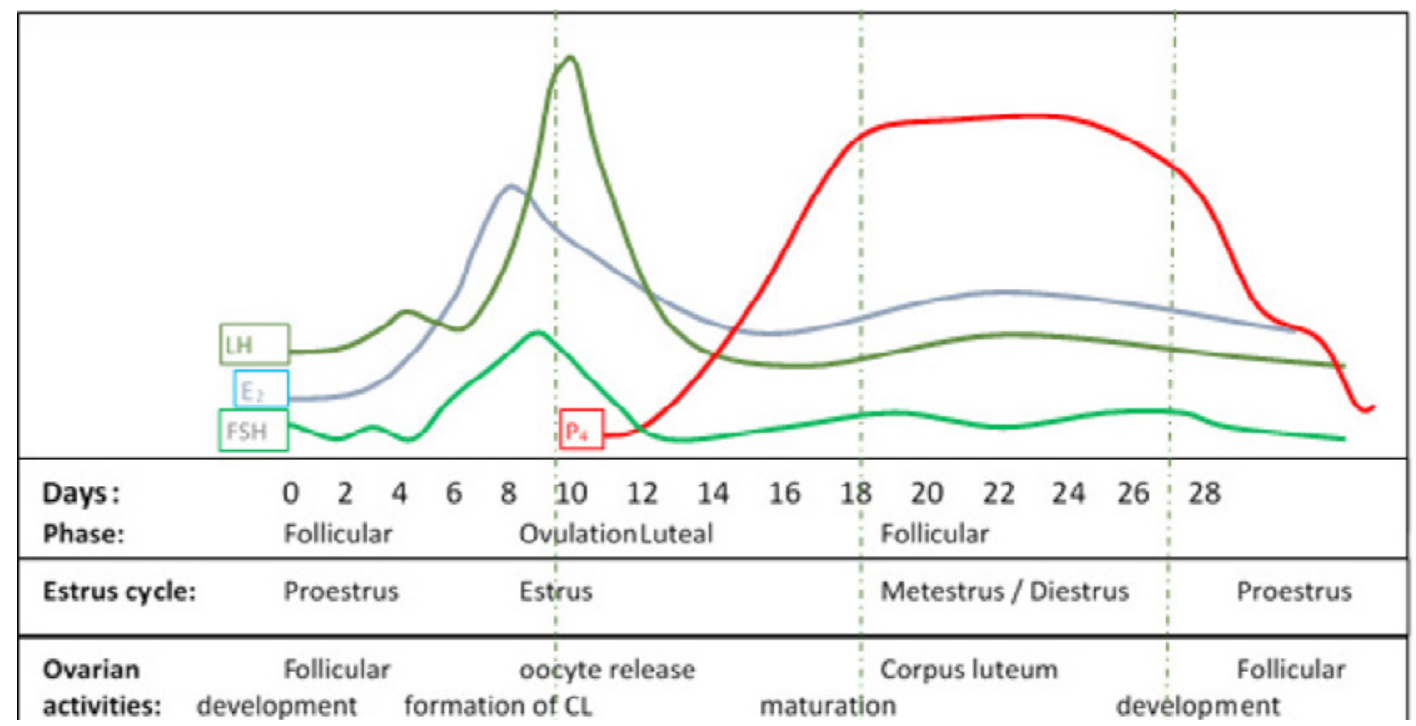

Figure 4 - Example of hormonal changes during an estrous cycle, without contraceptive influences Source: Pineda et al. (2003) and Rosenfield (2016) 
A simplified representation of estrus cycles under the influence of two types of contraceptives (Figure 5). GnRH analogue: the administration of a GnRHanalog implant, resulting in an initial flare response of LH and FSH secretion, and subsequent sharp drop, until an inhibitory effect on gonadotropin secretion, as long as the GnRH implant maintains its bioactivity (FINCH et al., 2009).

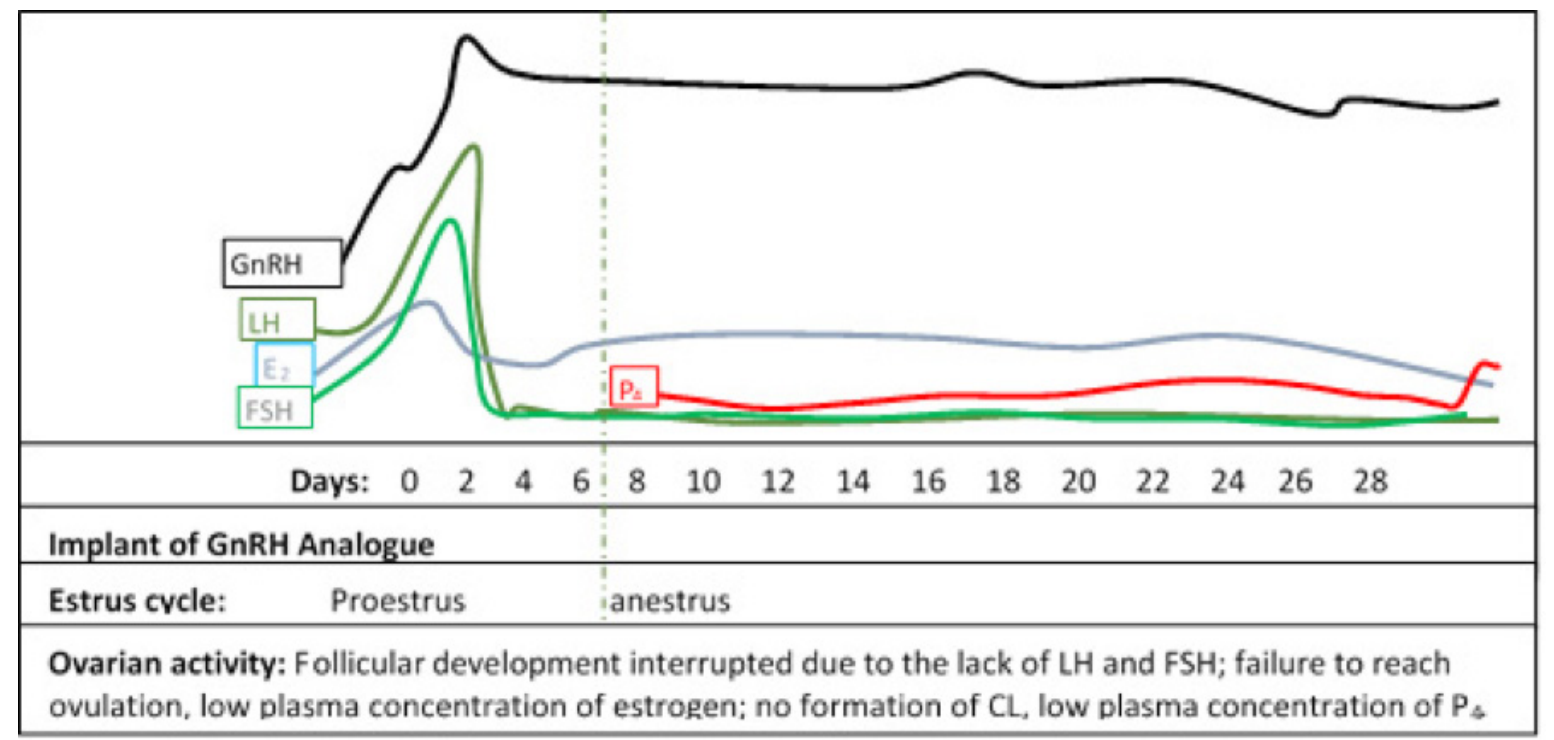

Figure 5 - Estrus cycle under the GnRH-analog contraceptive influence

Source: Pineda et al. McDonald (2003) and Rosenfield (2016)

\section{Steroid-based contraception}

Administration of the safer combo-contraceptive, such as an estrogen and progesterone agent, functions basically by tricking the body into believing it is already pregnant. Plasma levels of estrogen and progesterone remain constant throughout the treatment (Figure 6), resulting in failure to produce an estrogen and LH peak, and consequently no ovulation occurs, with an added effect of preventing fertilization mechanically, through a thickening of the cervical mucus, interfering with sperm motility (MARTIN; BARBIERI, 2016).

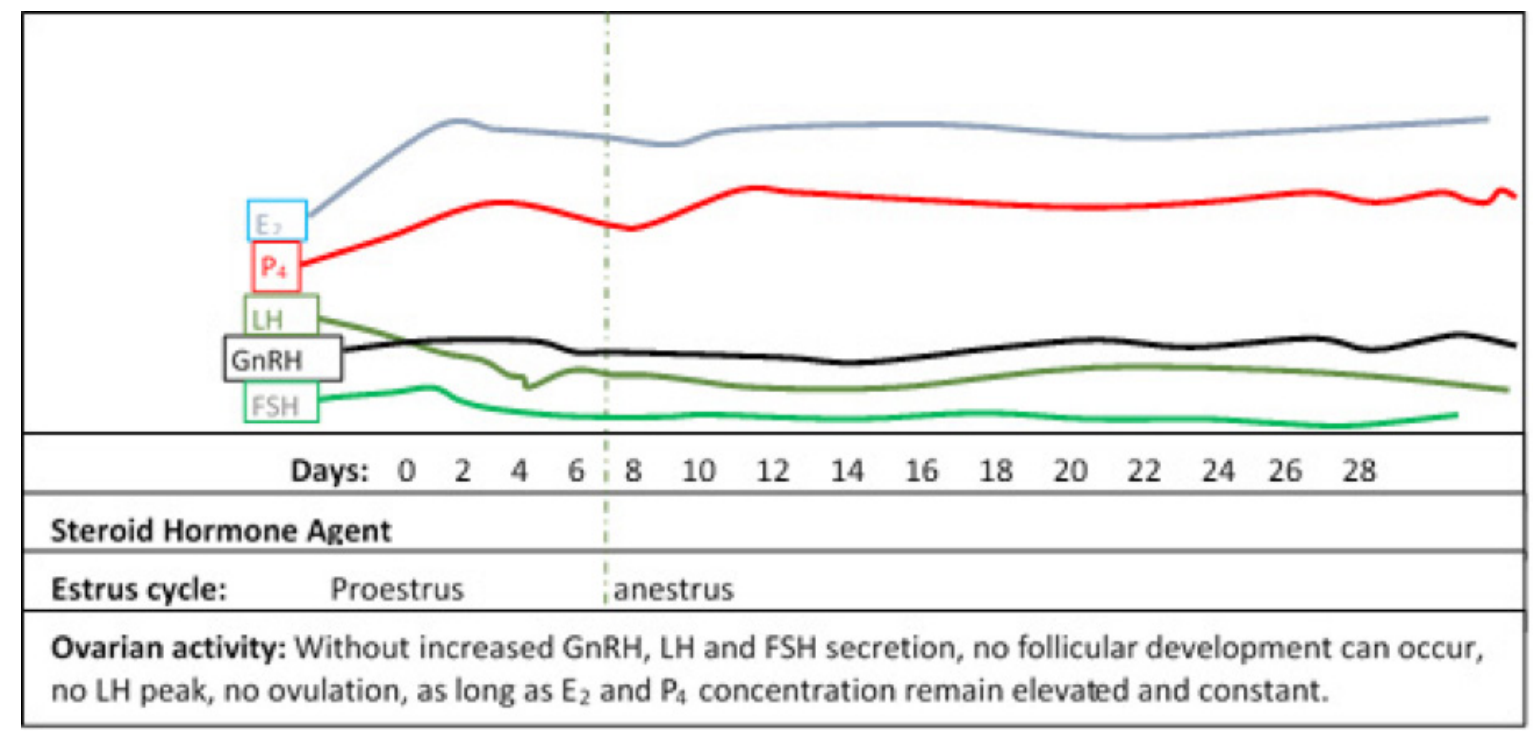

Figure 6 - Estrus cycle under steroid-hormone contraceptive influence Source: adapted from Pineda et al. (2003) and Rosenfield (2016) 


\section{Contraceptive methods in wildlife population control}

Not considering social and individual behavioral impacts, nor potential risks of adverse effects, contraceptive methods available for wildlife species may be divided into:

1) Reversible:

a) physical separation: the oldest, easiest, safest, and cheapest method, if space requirement is of no concern;

b) surgical procedures, examples: vasectomy in males - technically considered reversible, but that depends on several factors to be done so successfully (in reality, however, and depending on the species treated, occurrence of intensive inflammatory processes, and formation of scar tissue, there is a potential risk of non-reversibility); tubal ligation in females - under field conditions, all considered impractical, costly, often impossible and dangerous, especially with a larger number of animals to be treated;

c) chemical contraception: exogenous hormone-based contraceptives through oral, injection, or implant via for males and females, with steroid or non-steroid hormones;

d) immunocontraceptive vaccines (male and female);

e) chemical castration male and female depending on treatment duration, concentration, and the agent used, considered reversible in many cases;

f) mechanical: by obstruction, such as the Vas Plugin males, or the IUDs and sponges, some in combination with hormone preparations for female application.

\section{2) Non-reversible:}

a) surgical procedures: orchiectomy (removal of the testis) for males and ovary-salpingo- hysterectomy (removal of the ovaries, fallopian tubes, and the uterus) for females.

Which contraceptive method should be employed at the end depends on the chosen strategy, regarding short or long-term effects, applicability in the field or in captivity, ease of administration, associated risks, logistic and costs involved, and, of course, the species.

\section{The "perfect" contraceptive for wildlife species}

Proposed desired attributes:

- $\quad$ first and most importantly it should present no health risk for the individual;

- with little impact on secondary sexual characteristics;

- as little influence as possible on the individual and on the overall social group behavior;

- In most circumstances, it is desired that it offers $100 \%$ reversibility;

- offering long-term anti-fertility effects;

- $\quad$ applicable in both genders;

- easy administration (especially long distance);

- one-time (shot) only, meaning no refresher or booster needed;

- economically feasible for any wildlife management program;

- regarding environmental considerations - it should not pass through the food chain;

- it should not turn into a major pollutant (KIRKPATRICK; RUTBERG, 2001; LIU, 2011).

\section{Hormone-based contraceptive agents}

Antifertility drugs that act on the endocrine system are based either on steroid- or non- steroid (glycoprotein, peptide) hormones, and are mainly developed for human application, mostly for women. Because of their relative easy application, (orally, injected, or implanted), their efficiency, and not less important, relatively low costs, they are most commonly used in the treatment of domestic animals and captive wildlife (ASA; PORTON, 2005; PICKARD; HOLT, 2007; LIU, 2011; GARSIDE et al., 2014; ROSENFIELD, 2016). They may act at any given point along the hypothalamic-pituitary-gonadal axis, including feedback signaling. Either as an agonist or an antagonist, for example, inhibiting synthesis and secretion of GnRH, and subsequently LH/FSH hormones - consequently ceasing gonadal activities, such as sex-hormone synthesis and gametogenesis. They may also modulate the function of the female reproductive apparatus, bringing about desired contraceptive effects, like obstructing the transport of the ovum, blocking sperm passage and impending implementation of the egg on the endometrium. Nevertheless, steroid hormone-based contraceptives are very potent and may bind to non-target receptors. For 
instance, a progestin may bind to an androgenic receptor (AR) and cause androgenic effects, or an estrogenic effect, by binding to estrogen $\alpha$ and $\beta$ receptors (ER), possibly triggering several undesired cell responses, leading to serious side effects (DELIGDISCH, 2000; MUNSON et al., 2002; PINEDA et al., 2003; ASA; PORTON, 2005; MCALOOSE et al., 2007; DAVTYAN, 2012; ASA et al., 2014).

Most commonly used hormone contraceptives are progestin only, or progestin-estrogen combination, which require smaller dosages and are safer (SITRUK-WARE, 2006). As stated by Asa (2005), MGA (melengestrol acetate), a progestin, is the most commonly used contraceptive in US zoos, mainly due to its availability and effectiveness in a wide range of species.

As this article focuses on free-ranging wildlife mammals, intra-uterine devices are not being particularized, although frequently used in domestic and zoo environments.

\section{The immune system: self, non-self, and the concept of vaccines}

In general, the immunocontraceptive methods take advantage of the body's immune system and its protective mechanism to discriminate, by identifying indigenous (self) and marking, attacking, and eliminating foreign (non-self) proteins, allowing to fight off infectious diseases. Non-self materials or antigens are being marked by the presence of antibodies - specific to a group of organisms, or very similar ones. When the body's own defense mechanism acquires immunity, it is termed "active immunity" and may last many decades, even a lifetime. If provided by external means, it is called "passive immunity", either introduced with the first milk given by the mother to the offspring (colostrum), or transplacental, or after being produced by a mammalian animal, harvested, and transferred as a vaccine, via bait or injection, to another animal. Although a very effective protection, its shortcoming is its limited temporary activity, lasting normally only a few weeks to months. However, today this is less of an issue, with the development of slow-release technologies, capable of providing protection that may last years. Even though the strongest immune response is with live microorganisms, these antigens do not need to be alive in order to trigger a response. For safety reasons, vaccines contain foreign inactivated or killed pathogenic microorganisms that mimic a real infection, but without the infection and associated complications.
The concept of immunocontraception provokes the production of antibodies against the antigen, binding to the body's own reproductive protein, hormone, or receptor (autoimmune response), either causing a barrier, or the formation of large molecular structures (change of protein structure $=$ change of function), thus inhibiting their native role in the fertility mechanism as long as a sufficiently high concentration (titer) of antibodies is present (HERR, 1996; BARBER; FAYRER-HOSKEN, 2000; DELVES, 2004; TIZARD, 2009; MOSER; LEO, 2010; CROY, 2014).

\section{The role of adjuvants}

Besides the active ingredient, a vaccine is made up of adjuvants, (lat. adiucare: to aid), which are important additives to vaccines, improving the innate immune response (antibody and T lymphocyte) by increasing the inflammatory response as would a real infection, which in turn is important for an optimized adaptive immune response. Unfortunately, adjuvants are known to have their own set of potential health risks and are often associated with local injection-site reactions (LYDA et al., 2005; MUNSON et al., 2005).

Adjuvants may include organic components which may be liposomes, a spherical vesicle with a minimum of one lipid-bilayer, used as a vehicle for pharmaceutical drugs, lipopolysaccharides (LPS), part of endotoxins, parts of a bacterial cell walls, RNA, or DNA strands, alum (hydrated potassium aluminum sulfate), and emulsions (oil-inwater/water-in-oil mixtures), such as Freund's Incomplete Adjuvant (IFA).

Some adjuvants also function as a delivery system, causing the formation of depots at the injections site that traps the antigens, and allowing only a slow release of the vaccine components, maintaining a prolonged immunogenic stimulus while enhancing the overall immune response - a practice that allows "one-shot" (only one application), with long-term effects (ASA, 2005; SITRUK-WARE, 2006; MILLER et al., 2008; REED et al., 2013).

\section{Concepts of immunocontraception (immunological castration)}

Following the most commonly studied and employed contraceptives methods: female only (PZP, Porcine Zona Pellucida), male only (Eppin, epididymal protease inhibitor), or female and male (anti-GnRH antibody), see Figure 7. 


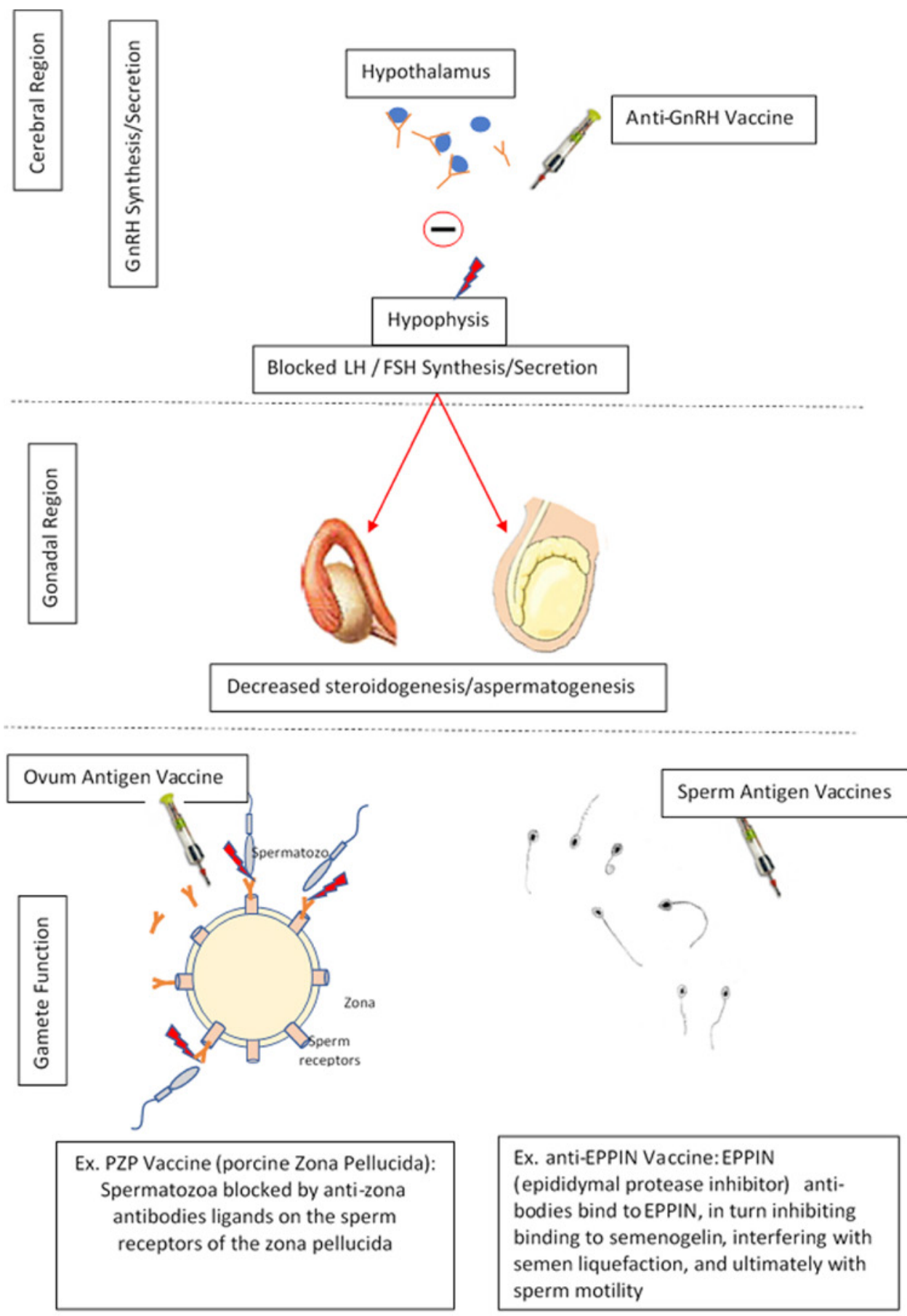

Figure 7 - Overview immunocontraceptive targets

Source: adapted from Liu et al. (2005) and Rosenfield (2016)

\section{Immunocontraceptive vaccine}

A non-cellular membrane surrounds the mammalian ovum, consisting of several glycoproteins, known as the zona pellucida (ZP). The glycoprotein ZP3 has been identified as the sperm-binding receptor (which permits the attachment of a spermatozoon to the ovum, in order to continue the next step of the fertilization process, leading to the diffusion of the sperm into the oocyte, creating a zygote). The pZP vaccine is produced by creating a zona pellucida antigen derived from porcine oocytes. Once the female is inoculated with the PZP vaccine, her immune system will respond by producing antibodies against the pig's oocyte antigen. The very same antibodies also bind to the sperm receptors on the ovum's surface (Figure 8), which will cause a distortion of the egg structure, thereby blocking sperm attachment, rendering the egg infertile without any other side effects or behavioral impacts (MILLER et al., 2001; LIU et al., 2005; KIRKPATRICK et al., 2010). 

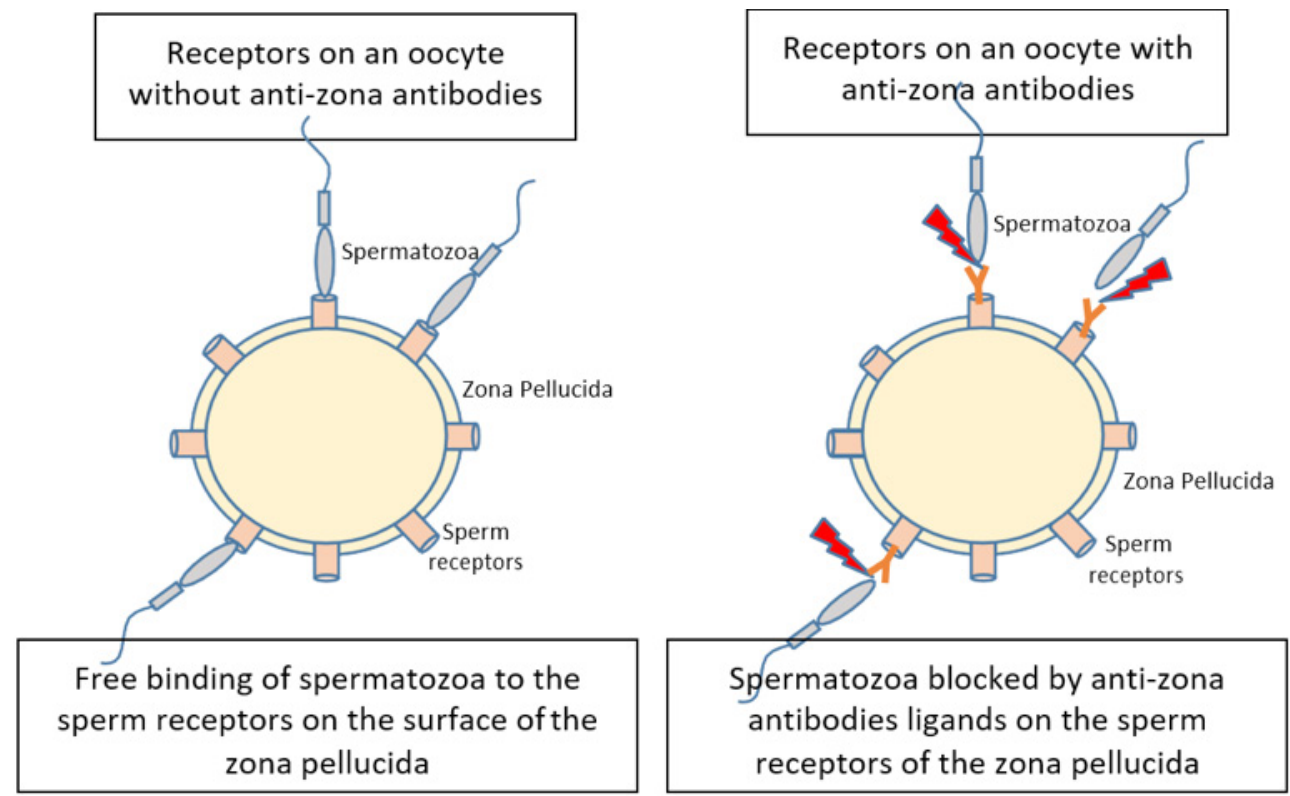

Figure 8 - PZP Vaccine; ZP sperm-binding receptors with and without anti-zona antibodies Source: adapted from Liu et al. (2005) and Rosenfield (2016)

\section{The mechanism of the GnRH immunocontraceptive vaccine}

The synthetic GnRH peptide is coupled to a foreign protein, like a hemocyanin protein, purified from the hemolymph of limpets (aquatic snails), together with a killed pathogenic microorganism, to enhance antigenicity. The elicited antibodies in this autoimmune response now mark native (self) GnRHs, forming large antibody-GnRH complexes. The inhibitory mechanism is not completely elucidated, offering two assumptions: (i) the newly formed protein complex has dimensions too large to diffuse through the capillary membrane of the hypophyseal portal system, thus not being able to reach GnRH receptors for $\mathrm{LH}$ and FSH synthesis at the adenohypophysis; and (ii) the GnRHAntibody structure prevents binding to corresponding GnRH receptors in the pituitary gland, consequently inhibiting gonadotropin secretion, ultimately preventing sex hormone synthesis and gametogenesis (Figure 9) (FAGERSTONE, 2006; MASSEI et al., 2008; MILLER et al., 2008; GRAY et al., 2010; SHARMA et al., 2014).



Figure 9 - GnRH Mechanism; normal and inhibited by anti-GnRH antibodies Source: adapted from Pineda et al. (2003) 


\section{The concept of immunocontraception: almost perfect for wildlife application?}

Although several articles mention immunocontraception as a "truly novel" concept, it is not quite the case, as first studies using the body's own immune system as an antifertility method started in the early 1930s (BASKIN, 1932). In-field application, procedures that require prior capture, tranquilization, and invasive procedures like implants, tubal ligation, and vasectomy are less feasible, but, of course, there are exceptions. Moreover, antifertility vaccines that require booster dosages are not practical.

\section{Discussion}

In order to choose between the immunocontraceptive of PZP or GnRH vaccines depends on the overall strategy on population control of a specific species, whether the targets are female, male, or both, among other factors. Unfortunately, there is no population control without having any impacts on the individual or the group. Specially in species with strong hierarchic social structures, targeting dominant males or females for contraception will have an intensive impact on the group's social behavior, perhaps even serious implications for its survival. The aim of free-ranging wildlife/feral population control is to avoid or minimize human-wildlife conflicts, and circumventing senseless killings, therefore leaving preoccupation about social impacts in second place. Anti-GnRH vaccines are not perfect, and there are real concerns about its use; nevertheless, recalling the wish-list's criterions, for the time being, what else is there?

- employable in both genders;

- "one-shot" only;

- highly effective (depending on species);

- long-term contraceptive effects (month to years, also depending on the species);

- very few adverse effects known (physiologic);

- no observed impacts on secondary sexual characteristics (lack of long-term studies);
- safe and quick administration (perfect for longdistance);

- last, but not least, reasonable cost to benefit ratio.

\section{Conclusion}

Research conducted on traditional contraceptive methods, steroid hormone and non-steroid hormone agents show important improvements, mainly by offering newer generations and combinations of synthetic steroid hormones that require smaller concentrations, hence, fewer side effects. Nevertheless, hormone treatments are problematic when it comes to the application in wildlife species, although still the most frequently used when it comes to population management for captive wildlife. Non-steroid hormones seem to be the next best alternative, as they offer long-term infertility effects with fewer health risks and provide better functionality when it comes to application in free-ranging as well as captive wildlife.

Immunocontraception is by far the most studied subject and scrutinized infertility method for domestic, free-ranging wildlife and feral species over the last ten years, for several before-mentioned reasons. Numerous empirical studies proved repeatedly its effectiveness in rendering various species infertile for extended periods of time, as stated by Miller (2009) in some cases up to 7 years. Unfortunately, in many studies investigating reversibility was not always available due to time constraints. Observed adverse effects were rare and, if apparent, none were severe. Most frequent adverse effects were vaccine-injection site injuries and the development of some persistent granulomas, due to extensive inflammatory reactions to the adjuvants, considered a necessary "evil", allowing to stimulate the immune response effectively enough while providing the slow-release effect, keeping the antibody titer adequately high, also maintaining contraception without the need for "booster" applications.

Looking at current and future research efforts, apparently, the focus stays on immunocontraceptives, with some promising new concepts to follow.

\section{References}

ABNEY, T. O. The potential roles of estrogens in regulating Leydig cell development and function: a review. Steroids, v. 64, n. 9, p. 610-617, 1999. doi: 10.1016/S0039-128X(99)00041-0.
ASA, C. S. Assessing efficacy and reversibility. In: ASA, C. S.; PORTON, I. J. (Eds.). Wildlife contraception: issues, methods and applications. Baltimore: Johns Hopkins University, 2005. p. 53-65. 
ASA, C. S.; BAUMAN, K. L.; DEVERY, S.; ZORDAN, M.; CAMILO, G. R.; BOUTELLE, S.; MORESCO, A. Factors associated with uterine endometrial hyperplasia and pyometra in wild canids: implications for fertility. Zoo Biology, v. 33, n. 1, p. 8-19, 2014. doi: 10.1002/zoo.21069.

ASA, C. S.; PORTON, I. J. Wildlife contraception: issues, methods, and applications. Baltimore: Johns Hopkins University, 2005. 256 p.

BARBER, M. R.; FAYRER-HOSKEN, R. A. Possible mechanismsofmammalianimmunocontraception.Journal of Reproductive Immunology, v. 46, n. 2, p. 103-124, 2000. doi: 10.1016/S0165-0378(99)00063-7.

BASKIN, M. J. Temporary sterilization by injection of human spermatozoa: a preliminary report. American Journal of Obstetrics \& Gynecology, v. 24, n. 6, p. 892-897, 1932. doi: 10.1016/S0002-9378(32)91129-6.

BERGER, P.; GRUSCHWITZ, M.; SPOETTL, G.; DIRNHOFER, S.; MADERSBACHER, S.; GERTH, R.; MERZ, W. E.; PLAS, E.; SAMPSON, N. Human chorionic gonadotropin(hCG)inthemalereproductivetract.Molecular and Cellular Endocrinology, v. 260-262, p. 190-196, 2007. doi: 10.1016/j.mce.2006.01.021.

BHATTI, S. F.; RAO, N. A.; OKKENS, A. C.; MOL, J. A.; DUCHATEAU, L.; DUCATELlE, R.; VAN DEN INGH, T. S.; TSHAMALA, M.; VAN HAM, L. M.; CORYN, M.; RIJNBERK, A.; KOOISTRA, H. S. Role of progestin-induced mammary-derived growth hormone in the pathogenesis of cystic endometrial hyperplasia in the bitch. Domestic Animal Endocrinology, v. 33, n. 3, p. 294-312, 2007. doi: 10.1016/j.domaniend.2006.06.005.

CHESTER-JONES, I.; INGLETON, P. M.; PHILLIPS, J. G. Fundamentals of comparative vertebrate endocrinology. New York: Springer, 2013. 666 p.

CLARKE, I. J.; POMPOLO, S. Synthesis and secretion of GnRH. Animal Reproduction Science, v. 88, n. 1-2, p. 29-55, 2005. doi: 10.1016/j.anireprosci.2005.05.003.

COOPER, D. W.; LARSEN, E. Immunocontraception of mammalian wildlife: ecological and immunogenetic issues. Reproduction, v. 132, n. 6, p. 821-828, 2006. doi: 10.1530/REP-06-0037.

CROY, B. A. Reproductive immunology issue one: cellular and molecular biology. Cellular \& Molecular Immunology, v. 11, n. 5, p. 405-406, 2014. doi: 10.1038/cmi.2014.64.

CUNNINGHAM, J. G.; KLEIN, B. G. Textbook of veterinary physiology. 4. ed. Saint Louis: Elsevier Saunders, 2007. 720 p.

DAVTYAN, C. Four generations of progestins in oral contraceptives. Proceedings of UCLA Healthcare, v. 16, p. 1-3, 2012. Available from: <https://goo.gl/zjnQXK>. Viewed: 14 Feb. 2016.

DELIGDISCH,L.HormonalPathologyoftheEndometrium. Modern Pathology, v. 13, n. 3, p. 285-294, 2000. doi: 10.1038/modpathol.3880050.

DELVES, P. J. How far from a hormone-based contraceptive vaccine? Journal of Reproductive Immunology, v. 62, n. 1-2, p. 69-78, 2004. doi: 10.1016/j.jri.2003.08.003.

DELVES, P. J.; LUND, T.; ROITT, I. M. Future prospects for vaccines to control fertility. Trends in Immunology, v. 23, n. 4, p. 220-221, 2002. doi: 10.1016/S1471-4906(02)02183-X.

FAGERSTONE, K. A. Mechanism of GnRH contraceptive vaccine-mediated infertility and its applications. In: INTERNATIONAL SYMPOSIUM ON NON-SURGICAL CONTRACEPTIVE METHODS OF PET POPULATION CONTROL, 3., 2006, Alexandria. Electronic proceedings... Alexandria: ACC\&D, 2006. Available from: <https://goo.gl/oVVLhx>. Viewed: 2 Mar. 2018.

FELDMAN, E. C.; NELSON, R. W. Canine and feline endocrinology and reproduction. 3. ed. St. Louis: Saunders, 2004. 1089 p.

FERRIE, G. M.; BECKER, K. K.; WHEATON, C. J.; FONTENOT, D.; BETTINGER, T. Chemical and surgical interventions to alleviate intraspecific aggression in male collared lemurs (Eulemur collaris). Journal of Zoo and Wildlife Medicine, v. 42, n. 2, p. 214-221, 2011. doi: 10.1638/2009-0193.1. 
FINCH, A. R.; CAUNT, C. J.; ARMSTRONG, S. P.; MCARDLE, C. A. Agonist-induced internalization and downregulation of gonadotropin-releasing hormone receptors. American Journal of Physiology: Cell Physiology, v. 297, n. 3, p. 591-600, 2009. doi: 10.1152/ajpcell.00166.2009.

GARSIDE, D.; GEBRIL, A.; ALSAADI, M.; FERRO, V. A. fertility control in wildlife: review of current status, including novel and future technologies. In: HOLT, W. V.; BROWN, J. L.; COMIZZOLI, P. (Eds.). Reproductive sciences in animal conservation. New York: Springer, 2014. p. 467-488. (Advances in Experimental Medicine and Biology Series, n. 753).

GRAY, M. E.; THAIN, D. S.; CAMERON, E. Z.; MILLER, L. A. Multi-year fertility reduction in free-roaming feral horses with single-injection immunocontraceptive formulations. Wildlife Research, v. 37, n. 6, p. 475-481, 2010. doi: 10.1071/WR09175.

GREGOIRE, A. T. Contraceptive steroids: pharmacology and safety. New York Springer, 2013. 395 p.

HADLEY, M. E.; LEVINE, J. E. Endocrinology. 6. ed. Upper Saddle River: Pearson, 2007. 500 p.

HERR, J. C. Immunocontraceptive approaches. In: HARRISON, P. F.; ROSENFIELD, A. (Eds.). Contraceptive Research and Development: looking to the future. Washington, DC: National Academies, 1996. p. 401-429.

\section{INTERNATIONAL UNION FOR CONSERVATION}

OF NATURE. Species Programme Member wins conservation award. Iucn.org, Gland, 2009. Available from: <https://goo.gl/77ZNjB >. Viewed: 2 Mar. 2018.

JOHNSON, M. H. Essential reproduction. 7. ed. Chichester: Wiley-Blackwell, 2013. 380 p.

KAUR, K.; PRABHA, V. Immunocontraceptives: new approaches to fertility control. BioMed Research International, v. 2014, p. 1-15, 2014. doi: 10.1155/2014/868196.
KIRKPATRICK, J. F. Fertility control: a new and successful paradigm for African elephant population management. Veterinary Sciences Tomorrow, v. 2011, p. 1-2, 2011. Available from: <https://goo.gl/BEivau>. Viewed: 18 Feb. 2016.

KIRKPATRICK, J. F.; RUTBERG, A. T. Fertility control in animals. In: SALEM, D. J.; ROWAN, A. N. (Eds.). The state of the animals: 2001. Washington, DC: Humane Society. p. 183-198. Available from: <https://goo.gl/ MC7RE9>. Viewed: 18 Feb. 2016.

KIRKPATRICK, J. F.; RUTBERG, A. T.; COATESMARKLE, L. Immunocontraceptive reproductive control utilizing Porcine Zona Pellucida (PZP) in federal wild horse populations. 3. ed. Billings: Science and Conservation Center, 2010. 42 p. Available from: <https://goo.gl/uDSEQJ>. Viewed: 2 Mar. 2018.

KOGAN, P.; WALD, M. Male contraception: history and development. Urologic Clinics of North America, v. 41, n. 1, p. 145-161, 2014. doi: 10.1016/j.ucl.2013.08.012.

LIU, I. K. M. A synopsis on contraception in wildlife and feral animals. Revista Brasileira de Reprodução Animal, v. 35, n. 2, p. 77-79, 2011. Available from: <https://goo.gl/JMqoJL>. Viewed: 18 Feb. 2016.

LIU, I. K. M.; TURNER JUNIOR, J. W.; VAN LEEUWEN, E. M. G.; FLANAGAN, D. R.; HEDRICK, J. L.; MURATA, K.; LANE, V. M.; MORALES-LEVY, M. P. Persistence of anti-zonae pellucidae antibodies following a single inoculation of porcine zonae pellucidae in the domestic equine. Reproduction, v. 129, n. 2, p. 181-190, 2005. doi: 10.1530/rep.1.00168.

LODISH, H. Overview of extracellular signaling. In: LODISH, H. Molecular cell biology. 4. ed. New York: W. H. Freeman, 2000.

LYDA, R. O.; HALL, J. R.; KIRKPATRICK, J. F. A Comparison of Freund's Complete and Freund's Modified Adjuvants used with a contraceptive vaccine in wild horses (Equus caballus). Journal of Zoo and Wildlife Medicine, v. 36, n. 4, p. 610-616, 2005. doi: 10.1638/04104.1. 
MARTIN, K. A.; BARBIERI, R. L. Overview of the use of estrogen-progestin contraceptives. UpToDate.com, [S.1.], 2016. Available from: <https://goo.gl/mQFHvE $>$. Viewed: 25 Jan. 2016.

MASSEI, G.; COWAN, D. P.; COATS, J.; GLADWELL, F.; LANE, J. E.; MILLER, L. A. Effect of the GnRH vaccine GonaCon on the fertility, physiology and behaviour of wild boar. Wildlife Research, v. 35, n. 6, p. 540-540, 2008. doi: 10.1071/WR07132.

MCALOOSE, D.; MUNSON, L.; NAYDAN, D. K. Histologic features of mammary carcinomas in zoo felids treated with melengestrol acetate (MGA) contraceptives. Veterinary Pathology, v. 44, n. 3, p. 320-326, 2007. doi: 10.1354/vp.44-3-320.

MEAD, E. J.; MAGUIRE, J. J.; KUC, R. E.; DAVENPORT, A. P. Kisspeptins: a multifunctional peptide system with a role in reproduction, cancer and the cardiovascular system. British Journal of Pharmacology, v. 151, n. 8, p. 1143-1153, 2007. doi: 10.1038/sj.bjp.0707295.

MILLER, L. A.; CRANE, K.; GADDIS, S.; KILLIAN, G. J. Porcine zona pellucida immunocontraception: longterm health effects on white-tailed deer. The Journal of wildlife management, v. 65, n. 4, p. 941-945, 2001. doi: $10.2307 / 3803042$.

MILLER, L. A.; FAGERSTONE, K. A.; WAGNER, D. C.; KILLIAN, G. J. Factors contributing to the success of a single-shot, multiyear PZP immunocontraceptive vaccine for white-tailed deer. Human-Wildlife Interactions, v. 3, n. 1, p. 103-115, 2009.

MILLER, L. A.; GIONFRIDDO, J. P.; FAGERSTONE, K. A.; RHYAN, J. C.; KILLIAN, G. J. The single-shot gnrh immunocontraceptive vaccine (GonaCon ${ }^{\mathrm{TM}}$ ) in whitetailed deer: comparison of several GnRH preparations. American Journal of Reproductive Immunology, v. 60, n.3,p.214-223,2008. doi: 10.1111/j.1600-0897.2008.00616.x.

MORESCO, A.; MUNSON, L.; GARDNER, I. A. Naturally occurring and melengestrol acetateassociated reproductive tract lesions in zoo canids. Veterinary Pathology, v. 46, n. 6, p. 1117-1128, 2009. doi: 10.1354/vp.08-VP-0293-M-FL.
MOSER, M.; LEO, O. Key concepts in immunology. Vaccine, v. 28, p. 2-13, 2010. Supplement 3. doi: 10.1016/j.vaccine.2010.07.022.

MUNSON, L.; GARDNER, I. A.; MASON, R. J.; CHASSY, L. M.; SEAL, U. S. Endometrial hyperplasia and mineralization in zoo felids treated with melengestrol acetate contraceptives. Veterinary Pathology, v. 39, n. 4, p. 419-427, 2002. doi: 10.1354/vp.39-4-419.

MUNSON, L.; HARRENSTIEN, L. A.; ACTON, A. E.; GRAHAM, P. A.; CHASSY, L. M.; KIRKPATRICK, J. F. Immunologic responses and adverse reactions to Freund'sadjuvanted porcine zona pellucida immune-contraceptives in domestic cats. Vaccine, v. 23, n. 48-49, p. 5646-5654, 2005. doi: 10.1016/j.vaccine.2005.05.044.

NELSON, R. J. An introduction to behavioral endocrinology. 3. ed. Sunderland: Sinauer, 2005. 822 p.

NISHIYAMA, T. Serum testosterone levels after medical or surgical androgen deprivation: a comprehensive review of the literature. Urologic Oncology, v. 32, n. 1, p. 17-28, 2014. doi: 10.1016/j.urolonc.2013.03.007.

PENFOLD, L. M.; BALL, R.; BURDEN, I.; JÖCHLE, W.; CITINO, S. B.; MONFORT, S. L.; WIELEBNOWSKI, $\mathrm{N}$. Case studies in antelope aggression control using a GnRH agonist. Zoo Biology, v. 21, n. 5, p. 435-448, 2002. doi: 10.1002/zoo.10079.

PICKARD, A. R.; HOLT, W. V. Contraception in wildlife. Journal of Family Planning and Reproductive Health Care, v. 33, n. 1, p. 48-52, 2007. doi: 10.1783/147118907779399602.

PINEDA, M. H.; DOOLEY, M. P.; MCDONALD, L. E. McDonald's veterinary endocrinology and reproduction. 5. ed. Ames: Iowa State, 2003. 573 p.

RACHEL, D. Methods for reducing aggression. Zoo Biology, v. 31, n. 2, p. 267-269, 2012. doi: 10.1002/zoo.20430.

REED, S. G.; ORR, M. T.; FOX, C. B. Key roles of adjuvants in modernvaccines. Nature Medicine, v. 19, n. 12, p.1597-1608, 2013. doi: $10.1038 / \mathrm{nm} .3409$. 
REITER, R. J.; TAN, D. X.; MANCHESTER, L. C.; PAREDES, S. D.; MAYO, J. C.; SAINZ, R. M. Melatonin and reproduction revisited. Biology of Reproduction, v. 81, n. 3, p. 445-456, 2009. doi: 10.1095/biolreprod.108.075655.

ROSENFIELD, D. A. Wildlife population control comprehensive and critical literature review on contraceptive methods in wildlife: mammals. 2016. 219 f. Dissertação (Mestrado em Reprodução Animal) - Departamento de Reprodução Animal, Faculdade de Medicina Veterinária e Zootecnia, Universidade de São Paulo, São Paulo, 2016.

ROTSTEIN, A. Sex hormone synthesis, regulation, and function. Pathophys.org, [S.1.], 2013. Available from: <https://goo.gl/tTKs0N>. Viewed: 22 Jan. 2016.

SHARMA, S.; MCDONALD, I.; MILLER, L.; HINDS, L. A. Parenteral administration of $\mathrm{GnRH}$ constructs and adjuvants: immune responses and effects on reproductive tissues of male mice. Vaccine, v. 32, n. 43, p. 5555-5563, 2014. doi: 10.1016/j.vaccine.2014.07.075.
SIMPSON, E.; RUBIN, G.; CLYNE, C.; ROBERTSON, K.; O'DONNELL, L.; DAVIS, S.; JONES, M. Local estrogen biosynthesis in males and females. Endocrine-Related Cancer, v. 6, n. 2, p. 131-137, 1999. doi: 10.1677/erc.0.0060131.

SITRUK-WARE, R. New progestagens for contraceptive use. Human Reproduction Update, v. 12, n. 2, p. 169-178, 2006. doi: 10.1093/humupd/dmi046.

SQUIRES, J. E. Applied animal endocrinology. Cambridge: CABI Publishing, 2013.

TASSIGNY, X. D.; COLLEDGE, W. H. The role of kisspeptin signaling in reproduction. Physiology, v. 25, n. 4, p. 207-217, 2010. doi: 10.1152/physiol.00009.2010.

TIZARD, I. R. Imunologia veterinária: uma introdução. 8. ed. São Paulo: Elsevier, 2009. 608 p.

ZOUBOULIS, C. C. The skin as an endocrine organ. Dermato-Endocrinology, v. 1, n. 5, p. 250-252, 2009. doi: 10.4161/derm.1.5.9499. 